\title{
Chemical Composition and Insecticidal and Repellent Effect of Essential Oils of Two Premna Species against Sitotroga cerealella
}

\author{
Elvis Adjalian, ${ }^{1,2}$ Philippe Sessou, ${ }^{1}$ Théophile Odjo, ${ }^{2}$ Gilles Figueredo, ${ }^{3}$ Dansou Kossou, ${ }^{2}$ \\ Félicien Avlessi, ${ }^{1}$ Chantal Menut, ${ }^{4}$ and Dominique Sohounhloué ${ }^{1}$ \\ ${ }^{1}$ Laboratoire d'Etude et de Recherche en Chimie Appliquée (LERCA), Ecole Polytechnique d'Abomey-Calavi/Université \\ d'Abomey-Calavi, 01 BP 2009 Cotonou, Benin \\ ${ }^{2}$ Laboratoire de Production Végétale, Faculté des Sciences Agronomiques/Université d’Abomey-Calavi, 01 BP 526 Cotonou, Benin \\ ${ }^{3}$ Laboratoire d'Analyse des Extraits Végétaux et des Arômes (LEXVA Analytique), 460 rue du Montant, 63110 Beaumont, Benin \\ ${ }^{4}$ Institut des Biomolécules Max Mousseron, Equipe "Glyco et Nanovecteurs pour le Ciblage Thérapeutique", Faculté de Pharmacie, \\ 15 avenue Charles Flahault, BP 14491, 34093 Montpellier, France
}

Correspondence should be addressed to Dominique Sohounhloué; ksohoun@bj.refer.org

Received 2 March 2015; Revised 26 June 2015; Accepted 8 July 2015

Academic Editor: Fedai Erler

Copyright (C) 2015 Elvis Adjalian et al. This is an open access article distributed under the Creative Commons Attribution License, which permits unrestricted use, distribution, and reproduction in any medium, provided the original work is properly cited.

\begin{abstract}
This work aims to study for the first time the chemical composition and evaluate insecticidal and repellent effects of essential oils of Premna angolensis and Premna quadrifolia leaves, against Sitotroga cerealella, an insect pest of rice stocks as alternatives to synthetic pesticides. The GC-MS analysis showed that essential oil of P. angolensis contains 29 compounds representing $96.1 \%$ of the oil and 42 compounds corresponding to $91 \%$ for the essential oil of $P$. quadrifolia. The main constituents regardless of the species were $\beta$-caryophyllene (13.1\%), (E)- $\beta$-caryophyllene (13.5\%), octen-3-ol (3.2\%-28\%), phytol (3.7\%-4.9\%), $\beta$-elemene $(1.4 \%-21 \%)$, globulol (11.2\%), germacrene-D (8.9\%), $\alpha$-humulene (2.9\%-6.4\%), $\alpha$-pinene (5\%), sabinene (3.7\%), $\delta$-cadinene $(0.4 \%-3.3 \%)$, and linalool (3.3\%). The results of laboratory tests showed that both essential oils have insecticidal and repellent effects on $S$. cerealella. Presenting the results, the damage caused by the adults and larvae of $S$. cerealella was evaluated by calculating the percentage of grains attacked and weight loss thereof. The results suggest that volatile extracts of $P$. angolensis and $P$. quadrifolia can be used as alternatives to synthetic chemicals in paddy protection against $S$. cerealella.
\end{abstract}

\section{Introduction}

The genus Premna L. (Verbenaceae) contains about 200 species worldwide, which are distributed mainly in tropical and subtropical parts of Asia, Africa, Australia, and the Pacific Islands $[1,2]$. Previous studies on chemical constituents of the genus Premna led to the isolation of triterpenes, diterpenes, and sesquiterpenes [3], some of them exhibiting significant antibacterial activities [4]. When antiparasitic activity of new Caledonian medicinal plants including Premna serratifolia L. was evaluated, it was observed that $P$. serratifolia was active against Leishmania donovani with $\mathrm{IC}_{50}$ values between 0.5 and $5 \mu \mathrm{g} \cdot \mathrm{mL}^{-1}$ [5]. In addition, some preparations of plants of the genus Premna have been used in the treatment of liver disorders and antioxidant as well as for their immune modulatory effects [6] in the traditional Indian system of medicine. The Premna genus can be used in treating various ailments like rheumatism, asthma, dropsy, cough, fever, boils, and scrofulous disease. Traditionally in tropical Africa and Benin in particular, people with low purchasing power very often use odors produced by aromatic plants collected locally for the control of insects. This is the case of Premna angolensis Gürke and Premna quadrifolia Schum. \& Thonn., leaves of which are burned and used by producers, as a fumigant in the attics of cereals against pests. In this study, extracts from leaves of both species $P$. angolensis and $P$. quadrifolia harvested in Benin were analyzed by gas chromatography-mass spectrometry (GC/MS) for the first time. The insecticidal 
and repellent activities were tested on the Angoumois grain moth Sitotroga cerealella (L.) (Lepidoptera: Gelechiidae) in rice storage.

\section{Material and Methods}

2.1. Plant Material and Distillation of the Volatile Constituents. Leaves of $P$. angolensis and $P$. quadrifolia were collected from the municipality of Comé by the authors and certified at the National Herbarium of Abomey-Calavi University. The collected plant materials were stored in the laboratory between 18 and $20^{\circ} \mathrm{C}$ in the shade of the sunlight throughout the period of extraction. The essential oils were obtained by hydrodistillation of the leaves $(450 \mathrm{~g})$ for five hours using a Clevenger-type extractor according to British Pharmacopoeia method [7]. They were then dried over anhydrous sodium sulfate and analyzed by GC/MS.

2.2. Test Organisms. Individuals of $S$. cerealella used for mass rearing for this study come from the reserve WARDA (Benin). Rearing conditions were $T=29 \pm 2^{\circ} \mathrm{C}, \mathrm{RH}=70 \pm 10 \%$.

\subsection{Analysis of the Volatile Constituents}

2.3.1. GC/MS. The essential oils were analysed on a HewlettPackard gas chromatograph Model 7890, coupled to a Hewlett-Packard MS Model 5875, equipped with a DB5 MS column $(30 \mathrm{~m} \times 0.25 \mathrm{~mm} ; 0.25 \mu \mathrm{m})$, programming from $50^{\circ} \mathrm{C}$ $(5 \mathrm{~min})$ to $300^{\circ} \mathrm{C}$ at $5^{\circ} \mathrm{C} / \mathrm{min}, 5 \mathrm{~min}$ hold. Helium was used as carrier gas $\left(1.0 \mathrm{~mL} \mathrm{~min}^{-1}\right)$; injection was made in split mode (1:30); injector and detector of temperature were at 250 and $280^{\circ} \mathrm{C}$, respectively. The MS working in electron impact mode was at $70 \mathrm{eV}$; electron multiplier was $2500 \mathrm{eV}$; ion source temperature was $180^{\circ} \mathrm{C}$; mass spectra data were acquired in the scan mode in $m / z$ range $33-450$.

2.3.2. GC/FID. The essential oils were analyzed on a HewlettPackard gas chromatograph Model 6890, equipped with a DB5 MS column $(30 \mathrm{~m} \times 0.25 \mathrm{~mm} ; 0.25 \mu \mathrm{m})$, programming from $50^{\circ} \mathrm{C}(5 \mathrm{~min})$ to $300^{\circ} \mathrm{C}$ at $5^{\circ} \mathrm{C} / \mathrm{min}, 5 \mathrm{~min}$ hold. Hydrogen was used as carrier gas $\left(1.0 \mathrm{~mL} \mathrm{~min}^{-1}\right)$; injection was in split mode $(1: 60)$; injector and detector temperature were 280 and $300^{\circ} \mathrm{C}$, respectively. The essential oil was diluted in hexane: $1 / 30$. The compounds assayed by GC in the different essential oils were identified by comparing their retention indices with those of reference compounds in the literature and confirmed by GC-MS by comparison of their mass spectra with those of reference substances [8-10].

2.4. Test. All tests were performed at a temperature of $29 \pm 2^{\circ} \mathrm{C}$ and natural photoperiod with relative humidity $70 \pm 10 \%$.

2.5. Contact Toxicity Tests with Essential Oils. Bioassays were performed using the method described by Noudogbessi et al. [11]. The temperature of the test medium ranged from $25^{\circ} \mathrm{C}$ to $31^{\circ} \mathrm{C}$ and relative humidity was $80 \%$. Five concentrations $\left(0,3,5,10\right.$, and $\left.15 \mu \mathrm{L} \mathrm{mL}^{-1}\right)$ depending on the selected

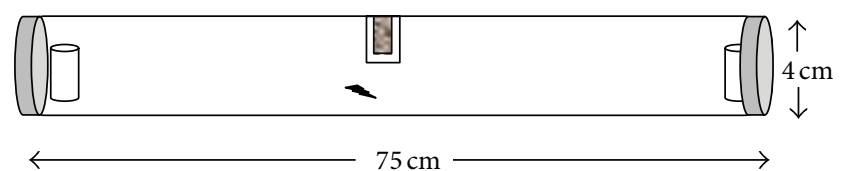

Figure 1: Olfactometer set-up. An individual female Angoumois grain moth was introduced in the center of the tube. Her position was recorded after $15 \mathrm{~min}$ since introduction. Treated and control paddy rice were positioned at either end of the tube.

chemical profile of each essential oil in absolute ethanol solution were tested. The plant material, paddy rice grains of the variety "IR841," was treated with each essential oil. After $24 \mathrm{~h}, 5$ males and 10 females of $S$. cerealella, aged 0 to $24 \mathrm{~h}$, were deposited on the treated plant material. Overall, 5 doses $\times 3$ repeats $\times 2$ types of oil $=30$ experimental units (containers) were implemented. The control sample treated only with ethanol was also infested by $S$. cerealella. Adult mortality was monitored $96 \mathrm{~h}$ after exposure to the essential oils. Then the insects were separated from the grains. The emergence of new insects was then observed at intervals of $24 \mathrm{~h}$ in the experimental units to the 50th day after infestation. Assessment concerned the rate of infested grains and weight loss of grains of rice.

To assess the $S$. cerealella damage on the rice seeds after treatment, the substrate grains were collected, counted, and weighed. The rate of weight loss of dry material of the grains was determined according to MCP (Method of Counting and Weighing) and MSVW (Method of Standard Volumetric Weight) [12]. Two criteria of assessment of the damage are commonly used: the percentage of attack of grains $(A \%)$ and percentage of weight loss $(B \%)$ [13], respectively, calculated by the equations:

$$
\begin{aligned}
A \% & =\frac{\mathrm{Na}}{\mathrm{Na}+\mathrm{Ns}} \times 100, \\
B \% & =\frac{\mathrm{PsNa}-\mathrm{PaNs}}{\mathrm{Ps}(\mathrm{Na}+\mathrm{Ns})} \times 100,
\end{aligned}
$$

where $\mathrm{Na}$ is number of attacked grains, Ns is number of healthy grains, $\mathrm{Pa}$ is weight of damaged grains, and $\mathrm{Ps}$ is weight of healthy grains.

2.6. Repellency Tests. The repellent action of the plants was tested in an olfactometer (Figure 1), consisting of a $75 \mathrm{~cm}$ glass tube of $4 \mathrm{~cm}$ in diameter, with a $29 \mathrm{~mm}$ hole in the middle. At either end of the tube, a small jar was placed containing either $10.0 \mathrm{~g}$ containing paddy rice treated with only ethanol or $10.0 \mathrm{~g}$ of paddy rice seeds mixed with a solution of essential oil at concentrations $0.1 \%, 0.5 \%$, and $1 \%$. The hole in the middle was covered with gauze, whereas the ends of the tube were closed by putting a plastic petri dish against them. Air was gently (ca I mls) sucked away from the centre of the tube to prevent the accumulation of plant odor in the tube.

Ten female $S$. cerealella aged $24 \mathrm{~h}$ to $48 \mathrm{~h}$ were released one after the other in the middle of the tube through the hole. Insect behavior was observed and the position was recorded for $15 \mathrm{~min}$. Both volatile extracts were tested once before 
the second round. Insects were considered to have made a choice when entered in one of the jars containing rice grains or those who have reached the last twenty-five centimeters of the tube. For those who chose the middle of the tube, they have finally made a choice. The percentage of insects rejected was calculated using the following formula:

$$
\text { Percentage Repellency }(\%)=\frac{A-B}{A+B} \times 100 \text {, }
$$

where $A$ is average number of insects present in the untreated portion (insects repelled) and $B$ is average number of insects in the treated (not repelled insects) part.

The average percentage of repulsion for the essential oil was calculated and assigned according to previous ranking [14] to one of several repulsive classes ranging from 0 to $\mathrm{V}$ : class 0 (Percentage Repellency $(\mathrm{PR})<0,1 \%)$, class I $(\mathrm{PR}=0,1-$ $20 \%)$, class II (PR $=20,1-40 \%)$, class III ( $P R=40,1-60 \%)$, class IV $(\mathrm{PR}=60,1-80 \%)$, and class $\mathrm{V}(\mathrm{PR}=80,1-100 \%)$.

2.7. Statistical Analysis. The results from the observations were statistically processed by Analysis of Variance (ANOVA) using SAS (Statistical Analysis System) Version 9.1. Finally, an average of the percentages of the three results of the test was made. The results of statistical tests were considered significantly different if the probability of the hypothesis was less than or equal to $5 \%$.

\section{Results}

Chromatographic analysis of the essential oil extracted from leaves of $P$. angolensis detected 29 compounds representing $96.1 \%$ of the weight of the essential oil (Table 1). However sesquiterpenes hydrogenated (26.6\%) and oxygen (20\%) were predominant. As for P. quadrifolia, 43 compounds were identified representing $91 \%$ of the essential oil. It was dominated by the hydrocarbon sesquiterpenes (65.5\%) (Table 1$)$. The predominant compounds of the two essential oils, regardless of species and their origin, were $\beta$-caryophyllene $(13.1 \%)$, (E)- $\beta$-caryophyllene (13.5\%), octen-3-ol (3.2\%-28\%), phytol $(3.7 \%-4.9 \%), \beta$-elemene $(1.4 \%-21 \%)$, globulol $(11.2 \%)$, germacrene-D (8.9\%), $\alpha$-humulene $(2.9 \%-6.4 \%), \alpha$-pinene $(5 \%)$, sabinene $(3.7 \%), \delta$-cadinene $(0.4 \%-3.3 \%)$, and Linalool (3.3\%).

The results of the estimation of the influence of different concentrations ( 0 to $15 \mu \mathrm{L} \mathrm{mL}^{-1}$ ) of the two essential oils on adult mortality of $S$. cerealella, the emergence of young insects, the rate of grains attacked, and loss corresponding weights are shown in Tables 2 and 3. Mortality rates of insects in Table 2 were obtained 4 days after treatment of the grains of paddy rice which ranged between 0 and concentrations $15 \mu \mathrm{L} \mathrm{mL}^{-1}$. At a concentration of $3 \mu \mathrm{L} \cdot \mathrm{mL}^{-1} P$. angolensis essential oil showed over $90 \%$ mortality through its contact activity on the adults of $S$. cerealella. The number of grains damaged and the loss of the weight of rice decrease when the dose of essential oil increases. The insecticidal effect of $P$. quadrifolia essential oil was less noticed compared to the essential oil of $P$. angolensis, with significant difference $(P<$ $0.001)$. In the controls sample, we noticed that the number of adults of $S$. cerealella increased rapidly and reached the rate of $89.62 \pm 0.01$ with $P$. quadrifolia and $85.71 \pm 0.03$ with $P$. angolensis.

Repellent Effect of Essential Oils Tested. The percentages of repulsion for the different doses of the essential oil of the leaves of $P$. quadrifolia and $P$. angolensis are summarized in Table 4 . The different doses of essential oils $(0.1 \%, 0.5 \%$, and $1 \%$ ) caused $67.11 \%$ to $96.84 \%$ repellency for P. angolensis and $65.55 \%$ to $91.55 \%$ for $P$. quadrifolia. This clearly shows that the percentage of repulsion increases with the dose.

\section{Discussion}

The output value of the essential oil from the leaves of $P$. quadrifolia was relatively better $(0.102 \% \pm 0.005)$ than that of $P$. angolensis $(0.056 \% \pm 0.004)$. No data have been reported in the literature on the essential oils of those two species. Essential oils $P$. quadrifolia and $P$. angolensis showed different chemical compositions. They were potentially rich in sesquiterpenoid compounds. During this study, insecticidal and repellent activity of both oils against $S$. cerealella was valued according to the treatment and the dose of applied oil. Previous studies on other species of Premna showed that their chemical compositions were rich in caryophyllene, $\beta$-cadinene, $\alpha$-selinene, and phytol $[15,16]$. The insecticide nature of essential oils of $P$. angolensis and $P$. quadrifolia manifested by contact adult insects $S$. cerealella may be linked to the main volatile compounds extracted reportedly acting alone or in synergy with other minor constituents. In fact, the essential oil of the leaves of $P$. angolensis contains monoterpenes and oxygenated hydrocarbon such as $\alpha$-pinene and Oct-1-en-3-ol and Linalool which insecticidal properties have been demonstrated against Tribolium confusum, Tribolium castaneum, Sitophilus zeamais, Callosobruchus maculatus, and Rhyzopertha dominica [11, 17].

The repulsion rates evaluated of $P$. angolensis essential oil showed a greater repellent activity against adults of Angoumois grain moth than $P$. quadrifolia essential oil belonging, respectively, to the repulsive $\mathrm{V}$ and IV class, according to MC-Donald and Guyr [14] ranking. This can be explained by the strong offensive odor of both oil and confirm the use of the leaves by farmers in protecting their grain in some parts of Benin. Insect repellent effect of the extract of $P$. angolensis volatile proved more interesting than that of $P$. quadrifolia despite having a very low yield of essential oil.

The use of essential oils in the preservation of cereals is increasingly recognized [18]. Essential oils are nowadays known as neurotoxins acutely interfering with octopaminergic transmitters in Arthropods [19]. Different doses of oils caused highly significant mortality $(P<0.001)$ in comparison with the mortality rates in the controls. Paddy rice is the most common form of conservation; only $S$. cerealella species is likely to multiply in the paddy rice which confirms the results of previous work [20]. Increasing doses of oil also reduced significantly the emergence of adults 50 days after infestation rates. Such a reduction in emergence rates results from the manifestation of ovicidal or larvicidal volatile extracts, which have destroyed the development of some eggs 
TABLE 1: Yield and chemical composition of essential oil of P. angolensis and P. quadrifolia leaves.

\begin{tabular}{|c|c|c|c|c|}
\hline $\mathrm{N}^{\circ}$ & Name of the compound & RI & $\begin{array}{c}\text { Premna angolensis } \\
(\%)\end{array}$ & $\begin{array}{c}\text { Premna quadrifolia } \\
\text { (\%) }\end{array}$ \\
\hline 1 & (Z)-3-Hexen-1-ol & 850 & 1.0 & - \\
\hline 2 & $\alpha$-Pinene & 933 & 5.0 & - \\
\hline 3 & Sabinene & 965 & - & 3.7 \\
\hline 4 & $\beta$-Pinene & 970 & - & 0.6 \\
\hline 5 & Octen-3-ol & 973 & 28.0 & 3.2 \\
\hline 7 & Octan-3-one & 977 & 2.7 & - \\
\hline 8 & Myrcene & 987 & 0.3 & - \\
\hline 9 & Octan-3-ol & 991 & 1.4 & - \\
\hline 10 & $\alpha$-Phellandrene & 996 & - & 1.0 \\
\hline 11 & Limonene & 1022 & - & 1.9 \\
\hline 12 & $\beta$-Phellandrene & 1023 & - & 0.6 \\
\hline 13 & p-Cymene & 1024 & 0.5 & 0.8 \\
\hline 14 & Eucalyptol & 1025 & - & $\mathrm{t}$ \\
\hline 15 & Limonene & 1027 & 1.4 & - \\
\hline 16 & (E)- $\beta$-Ocimene & 1039 & - & 0.1 \\
\hline 17 & $\gamma$-Terpinene & 1051 & - & 0.1 \\
\hline 18 & (Z)-Sabinene hydrate & 1064 & - & 0.1 \\
\hline 19 & Linalool & 1096 & 3.3 & - \\
\hline 20 & Triacetonamine & 1108 & - & 2.8 \\
\hline 21 & Terpinen-4-ol & 1174 & 2.5 & 0.5 \\
\hline 22 & Naphthalene & 1178 & - & 0.9 \\
\hline 23 & $\alpha$-Terpineol & 1188 & - & 0.1 \\
\hline 24 & Methyl salicylate & 1194 & 2.2 & - \\
\hline 25 & Nerol & 1221 & $\mathrm{t}$ & - \\
\hline 26 & Ethyl salicylate & 1266 & $\mathrm{t}$ & - \\
\hline 27 & $\alpha$-Cubebene & 1339 & - & 0.2 \\
\hline 28 & $\alpha$-Ylangene & 1362 & - & 0.1 \\
\hline 29 & $\alpha$-Copaene & 1369 & - & 1.7 \\
\hline 30 & $\beta$-Elemene & 1374 & 1.4 & 21 \\
\hline 31 & (E)- $\beta$-Damascenone & 1384 & 1.2 & - \\
\hline 32 & $\alpha$-Gurjunene & 1400 & - & 2.0 \\
\hline 33 & $\beta$-Caryophyllene & 1414 & - & 13.1 \\
\hline 34 & $\gamma$-Elemene & 1421 & - & 1.1 \\
\hline 35 & (E)- $\beta$-Caryophyllene & 1424 & 13.5 & - \\
\hline 36 & (E)- $\alpha$-Bergamotene & 1424 & - & 0.8 \\
\hline 37 & Aromadendrene & 1443 & 0.6 & - \\
\hline 38 & (Z)- $\beta$-Farnesene & 1443 & - & 0.2 \\
\hline 39 & Alloaromadendrene & 1454 & - & 0.4 \\
\hline 40 & $\alpha$-Humulene & 1458 & 6.4 & 2.9 \\
\hline 41 & Selina-4,11-diene & 1466 & - & 1.1 \\
\hline 42 & Germacrene-D & 1475 & - & 8.9 \\
\hline 43 & $\beta$-Selinene & 1486 & 0.6 & 1.6 \\
\hline 44 & $\gamma$-Patchoulene & 1490 & 2.8 & - \\
\hline 45 & $\alpha$-Bulnesene & 1490 & - & 1.8 \\
\hline 46 & $\alpha$-Farnesene & 1494 & - & 0.8 \\
\hline 47 & $\delta$-cadinene & 1499 & 0.9 & - \\
\hline 48 & $\beta$-Bisabolene & 1499 & - & 1.9 \\
\hline 49 & Germacrene A & 1501 & - & 0.2 \\
\hline
\end{tabular}


TABLE 1: Continued.

\begin{tabular}{|c|c|c|c|c|}
\hline $\mathrm{N}^{\circ}$ & Name of the compound & RI & $\begin{array}{c}\text { Premna angolensis } \\
(\%)\end{array}$ & $\begin{array}{c}\text { Premna quadrifolia } \\
(\%)\end{array}$ \\
\hline 50 & $\gamma$-Cadinene & 1506 & - & 0.9 \\
\hline 51 & (Z)-Calamenene & 1512 & - & 0.4 \\
\hline 52 & $\delta$-Cadinene & 1525 & 0.4 & 3.3 \\
\hline 53 & Germacrene B & 1553 & - & 1.1 \\
\hline 54 & (E)-Nerolidol & 1562 & 0.7 & - \\
\hline 55 & Epiglobulol & 1565 & 2.2 & - \\
\hline 56 & Spathulenol & 1571 & - & 0.2 \\
\hline 57 & Caryophyllene oxide & 1577 & - & 1.3 \\
\hline 58 & Globulol & 1590 & 11.2 & - \\
\hline 59 & Humulene epoxide II & 1616 & 0.9 & - \\
\hline 60 & Epi- $\alpha$-muurolol & 1649 & - & 1.2 \\
\hline 61 & Selin-11-en-4- $\alpha$-ol & 1653 & - & 1.5 \\
\hline 62 & $\alpha$-Cadinol & 1658 & 1.0 & - \\
\hline 63 & Intermedeol & 1673 & 0.3 & - \\
\hline 64 & Phytol & 2048 & 3.7 & 4.9 \\
\hline \multicolumn{3}{|c|}{ Total (\%) } & 96.1 & $91 \%$ \\
\hline \multicolumn{3}{|c|}{ Yield (\%) } & 0.056 & 0.102 \\
\hline \multicolumn{3}{|c|}{ Hydrogenated monoterpenes (\%) } & 8.6 & 8.9 \\
\hline \multicolumn{3}{|c|}{ Oxygenated monoterpenes (\%) } & 9.2 & 4.3 \\
\hline \multicolumn{3}{|c|}{ Hydrogenated sesquiterpenes (\%) } & 26.6 & 65.5 \\
\hline \multicolumn{3}{|c|}{ Oxygenated sesquiterpenes (\%) } & 20 & 9.1 \\
\hline \multicolumn{3}{|c|}{ Oxygenated aliphatic compounds (\%) } & 31.7 & 3.2 \\
\hline
\end{tabular}

$\mathrm{t}$ (traces) $=0.1 \%$; RI: retention index.

TABLE 2: Rate of $S$. cerealella death, of emergence, of number of rice attacked $(A)$, and of weight loss $(B)$ provoked by $P$. angolensis essential oil in contact method.

\begin{tabular}{lcccc}
\hline Dose $\left(\mu \mathrm{L} \mathrm{mL}^{-1}\right)$ & Mortality & Emerged & $A(\%)$ & $B(\%)$ \\
\hline 0 & $18.78 \pm 0.07^{\mathrm{b}}$ & $85.71 \pm 0.03^{\mathrm{a}}$ & $25.19 \pm 2.41^{\mathrm{b}}$ & $22.726 \pm 1.955^{\mathrm{b}}$ \\
3 & $90.12 \pm 0.30^{\mathrm{a}}$ & $1.07 \pm 0.06^{\mathrm{b}}$ & $0.37 \pm 0.01^{\mathrm{c}}$ & $0.003 \pm 0.048^{\mathrm{c}}$ \\
5 & $94.26 \pm 0.17^{\mathrm{a}}$ & $0.40 \pm 0.11^{\mathrm{c}}$ & $0.32 \pm 0.020^{\mathrm{c}}$ & $0.046 \pm 0.028^{\mathrm{c}}$ \\
10 & $100 \pm 0.00^{\mathrm{a}}$ & $0.33 \pm 0.05^{\mathrm{cd}}$ & $0.26 \pm 0.02^{\mathrm{c}}$ & $0.003 \pm 0.024^{\mathrm{c}}$ \\
15 & $100 \pm 0.00^{\mathrm{a}}$ & $0.13 \pm 0.10^{\mathrm{d}}$ & $0.15 \pm 0.02^{\mathrm{c}}$ & $0.000 \pm 0.020^{\mathrm{c}}$ \\
Probability & $<0.001^{* * *}$ & $<0.001^{* * *}$ & $<0.001^{* * *}$ & $<0.001^{* * *}$ \\
CV $(\%)$ & 13.75 & 10.58 & 18.76 & 16.85 \\
\hline
\end{tabular}

0 : ethanol treatment (control); ${ }^{* * *}$ very highly significant difference $(0.1 \%)$.

The averages followed by the same letter were not significantly different at the beginning of $5 \%$.

TABLE 3: Rate of S. cerealella death, of emergence, of number of rice attacked $(A)$, and of weight loss $(B)$ provoked by $P$. quadrifolia essential oil in contact method.

\begin{tabular}{lcccc}
\hline Dose $\left(\mu \mathrm{L} \mathrm{mL}^{-1}\right)$ & Mortality & Emerged & $A(\%)$ & $B(\%)$ \\
\hline 0 & $10.82 \pm 0.17^{\mathrm{d}}$ & $89.62 \pm 0.01^{\mathrm{a}}$ & $25.44 \pm 0.93^{\mathrm{b}}$ & $24.31 \pm 0.28^{\mathrm{b}}$ \\
3 & $57.96 \pm 0.05^{\mathrm{c}}$ & $2.10 \pm 0.04^{\mathrm{b}}$ & $0.61 \pm 0.05^{\mathrm{c}}$ & $0.01 \pm 0.00^{\mathrm{c}}$ \\
5 & $70.38 \pm 0.00^{\mathrm{bc}}$ & $1.62 \pm 0.08^{\mathrm{b}}$ & $0.48 \pm 0.05^{\mathrm{c}}$ & $0.05 \pm 0.02^{\mathrm{c}}$ \\
10 & $76.75 \pm 0.12^{\mathrm{ab}}$ & $1.28 \pm 0.05^{\mathrm{b}}$ & $0.35 \pm 0.04^{\mathrm{c}}$ & $0.04 \pm 0.03^{\mathrm{c}}$ \\
15 & $88.85 \pm 0.17^{\mathrm{a}}$ & $0.13 \pm 0.10^{\mathrm{c}}$ & $0.07 \pm 0.01^{\mathrm{c}}$ & $0.04 \pm 0.01^{\mathrm{c}}$ \\
Probability & $<0.001^{* * *}$ & $<0.001^{* * *}$ & $<0.001^{* * *}$ & $<0.001^{* * *}$ \\
CV $(\%)$ & 14.21 & 7.51 & 7.90 & 6.02 \\
\hline
\end{tabular}

0 : ethanol treatment (control); ${ }^{* * *}$ very highly significant difference $(0.1 \%)$.

The averages followed by the same letter were not significantly different at the beginning of $5 \%$. 
TABLE 4: Percentage (\%) of the repellence with olfactometer of the essential oil of the leaves of $P$. angolensis and P. quadrifolia on adult Sitotroga cerealella.

\begin{tabular}{lcc}
\hline \multirow{2}{*}{ Dose $(\%)$} & \multicolumn{2}{c}{ Repellency rate $(\%)( \pm \mathrm{SD})$} \\
& P. angolensis & P. quadrifolia \\
\hline 0.1 & $67.11 \pm 10.95$ & $65.55 \pm 12.86$ \\
0.5 & $88 \pm 10.95$ & $83.55 \pm 9.24$ \\
1 & $96 \pm 8.94$ & $91.55 \pm 11.58$ \\
\hline Mean $( \pm \mathrm{SD})$ & $\mathbf{8 3 . 7 0} \pm \mathbf{1 . 1 6}$ & $\mathbf{8 0 . 2 2} \pm \mathbf{1 3 . 3 1}$ \\
Repellence class & $\mathbf{V}$ & IV \\
\hline
\end{tabular}

or larvae probably due to sesquiterpenoid compounds or oxygenated aliphatic and synergy with minor compounds.

\section{Conflict of Interests}

The authors declare that there is no conflict of interests regarding the publication of this paper.

\section{Acknowledgments}

The authors are grateful to Polytechnic School of AbomeyCalavi (Benin) for financial support. They are also thankful to Professor Aristide ADOMOU from National Herbarium of Benin for plants identification. The authors thank Dr. Noudogbessi that made the chemical analysis of essential oils in the laboratory of Professor Chantal Menut in France (may he rest in peace).

\section{References}

[1] J. W. Kadareit, "Flowering plants-dicotyledons," in The Families and Genera of Vascular Plants, K. Kubitzki, Ed., vol. 7, p. 449, Springer, 2004.

[2] J. Lovett and G. P. Clarke, "Premna schliebenii," in IUCN. 2006 Red List of Threatened Species, 1998.

[3] A. Hymavathi, K. S. Babu, V. G. M. Naidu, S. R. Krishna, P. V. Diwan, and J. M. Rao, "Bioactivity-guided isolation of cytotoxic constituents from stem-bark of Premna tomentosa," Bioorganic and Medicinal Chemistry Letters, vol. 19, no. 19, pp. 5727-5731, 2009.

[4] H. Sudo, T. Ide, H. Otsuka, E. Hirata, A. T. TakushiShinzato, and Y. Takeda, "Megastigmane, benzyl and phenethyl alcohol glycosides, and 4, $4^{\prime}$-dimethoxy- $\beta$-truxinic acid catalpol diester from the leaves of Premna subscandens MERR," Chemical and Pharmaceutical Bulletin, vol. 48, no. 4, pp. 542-546, 2000.

[5] J. Desrivot, J. Waikedre, P. Cabalion et al., "Antiparasitic activity of some new caledonian medicinal plants," Journal of Ethnopharmacology, vol. 112, no. 1, pp. 7-12, 2007.

[6] K. P. Devi, M. S. Ram, M. Sreepriya, G. Ilavazhagan, and T. Devak, "Immunomodulatory effects of Premna tomentosa extract against $\mathrm{Cr}$ (VI) induced toxicity in splenic lymphocytes - an in vitro study," Biomedicine \& Pharmacotherapy, vol. 57, no. 2, pp. 105-108, 2003.

[7] British Pharmacopoeia, 11. P. A. HMSO, London, UK, 1980.

[8] R. P. Adams, Identification of Essential Oil by Ion Trap Mass Spectrometry, Academy Press, New-York, NY, USA, 1989.
[9] P. Rösch, J. Popp, and W. Kiefer, "Raman and surface enhanced Raman spectroscopic investigation on Lamiaceae plants," Journal of Molecular Structure, vol. 480-481, pp. 121-124, 1999.

[10] A. A. Swigar and R. M. Silverstein, Monoterpenes, Infrared, Mass, NMR Spectra and Kovats Indices, Aldrich Chem, Milwaukee, Wis, USA, 1981.

[11] J. P. Noudogbessi, M. Keke, F. Avlessi, D. Kossou, and D. C. K. Sohounhloue, "Evaluation of the insecticidal, larvicidal and ovicidal effects on Callosobruchus maculatus of essential oils of Cymbopogon giganteus and of Xylopia aethiopica," Scientific Study \& Research, vol. 10, no. 4, pp. 337-338, 2009.

[12] C. U. Panthenius, "Etat des pertes dans les systèmes de stockages du maïs au niveau des petits paysans dans la région maritime au Togo," Fiche technique 83, GTZ, 1988.

[13] Centre d'Etude et d'Expérimentation du Machinisme Agricole et Tropical (CEEMAT), Conservation des Grains en Régions Chaudes: Techniques Rurales en Afrique, Centre d'Etude et d'Expérimentation du Machinisme Agricole et Tropical (CEEMAT), Paris, France, 1988.

[14] L. MC-Donald and H. D. Guyr, "Preliminary evaluation of new candidate materials as toxicants, repellents and attractants against stored product insects," Marketing Research Report 882, Agricultural Research Service, United State Department of Agriculture, Washington, DC, USA, 1970.

[15] P. K. Renjana and J. E. Thoppil, "Larvicidal activities of the leaf extracts and essential oil of Premna latifolia roxb. (verbenaceae) against Aedes albopictus Skuse (Diptera: Culicidae)," Journal of Applied Pharmaceutical Science, vol. 3, no. 6, pp. 101-105, 2013.

[16] C. T. Sadashiva, P. Sharanappa, Y. Naidoo, and I. Balachandran, "Chemical composition of essential oil from the leaves of Premna coriacea Clarke," African Journal of Biotechnology, vol. 12, no. 20, pp. 2914-2916, 2013.

[17] G. K. Ketoh, H. K. Koumaglo, and I. A. Glitho, "Inhibition of Callosobruchus maculatus (F.) (Coleoptera: Bruchidae) development with essential oil extracted from Cymbopogon schoenanthus L. Spreng. (Poaceae) and the wasp Dinarmus basalis Rondani (Hymenoptera: Pteromalidae)," Journal of Stored Products Research, vol. 41, pp. 363-371, 2006.

[18] A. Smith-Palmer, J. Stewart, and L. Fyfe, "The potential application of plant essential oils as natural food preservatives in soft cheese," Food Microbiology, vol. 18, no. 4, pp. 463-470, 2001.

[19] N. L. Tatsadjieu, P. M. J. Dongmo, M. B. Ngassoum, F.-X. Etoa, and C. M. F. Mbofung, "Investigations on the essential oil of Lippia rugosa from Cameroon for its potential use as antifungal agent against Aspergillus flavus Link ex. Fries," Food Control, vol. 20, no. 2, pp. 161-166, 2009.

[20] A. Togola, P. A. Seek, I. A. Glitho et al., "Economic losses from insect pest infestation on rice stored on-farm in Benin," Journal of Applied Sciences, vol. 13, no. 2, pp. 278-285, 2013. 

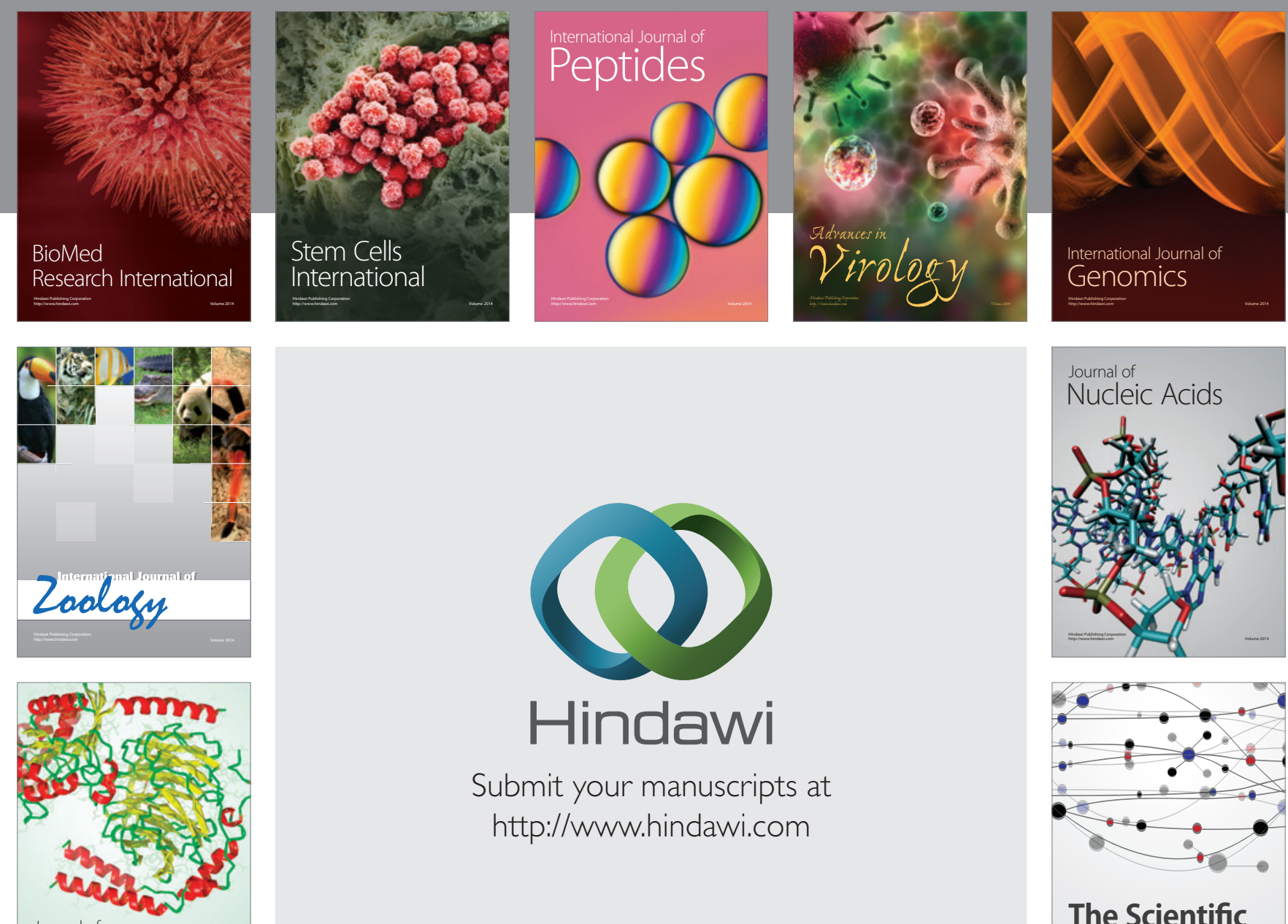

Submit your manuscripts at

http://www.hindawi.com

Journal of
Signal Transduction
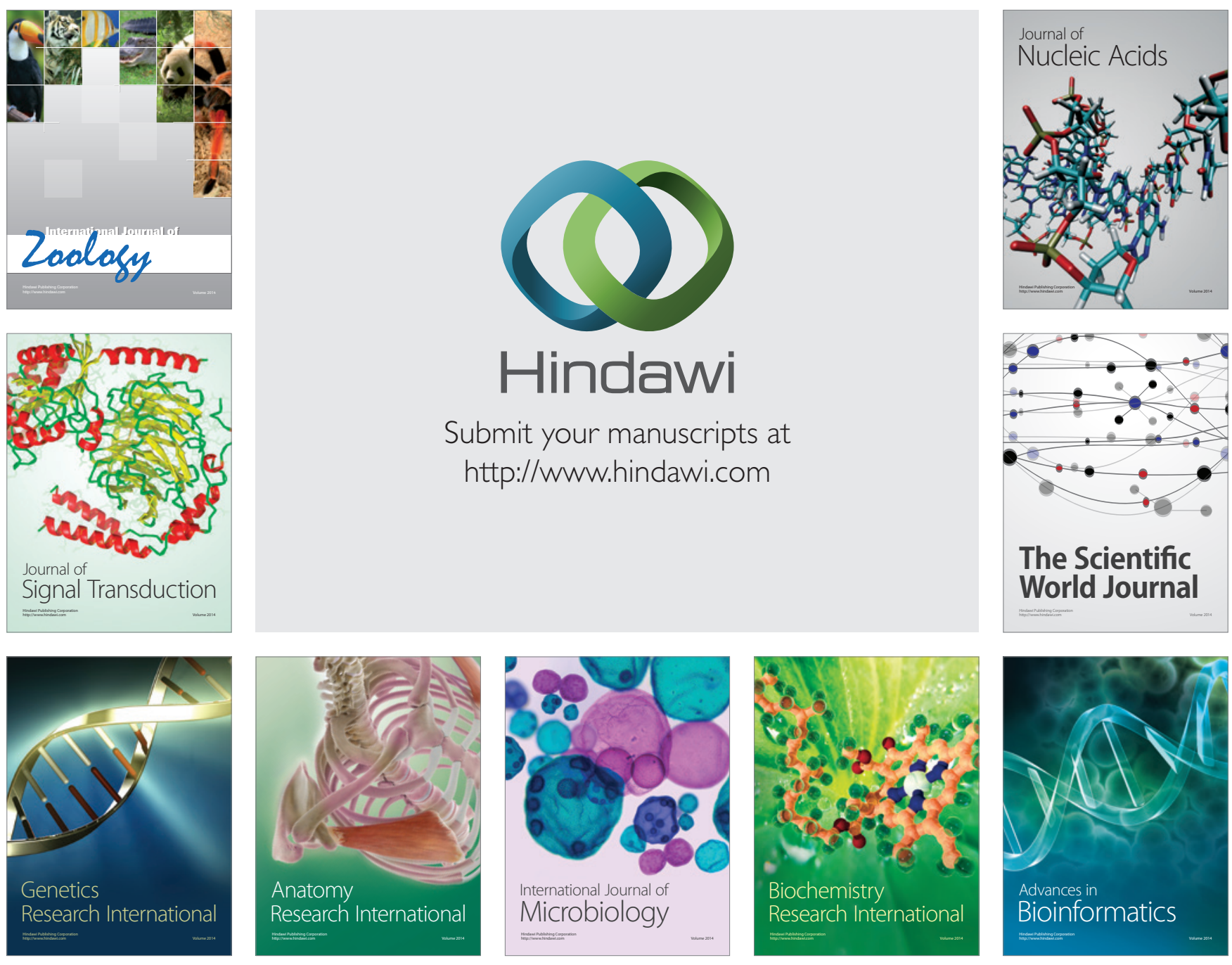

The Scientific World Journal
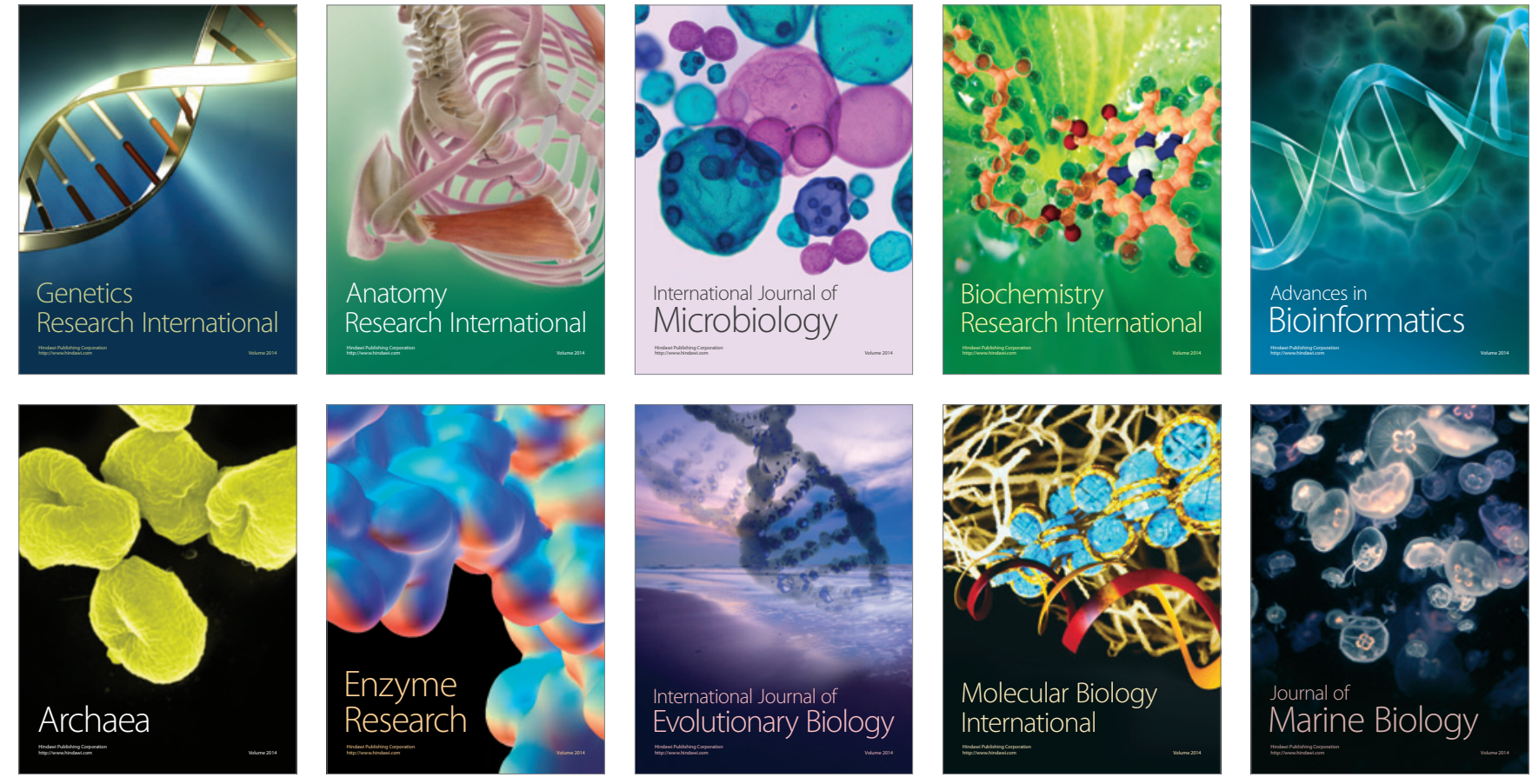